\title{
Regional differences in the attitudes of veterinary students in Croatia towards welfare of farm and companion animals
}

\author{
I. Sabolek, M. Ostovič́, T. Mikuš, Ž. Pavičić, K. Matković, B. Antunović \\ and Ž. Mesić
}

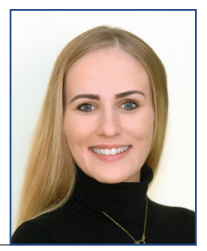

\begin{abstract}
The aim of this study was to examine the attitudes of veterinary students in Croatia based on region of their origin towards the level of cognitive abilities and compromised welfare in farm and companion animals. The survey encompassed 505 (91\%) students of all six years of the integrated undergraduate and graduate study programme at the Faculty of Veterinary Medicine, University of Zagreb, Zagreb, Croatia. Student attitudes were examined through 17 statements using five-point Likert scale. The survey was focused on cattle, pigs, poultry, dogs and cats. The results obtained revealed that students from Zagreb and central Croatia expressed significantly higher attitudes $(P<0.05)$ towards the level of thought process in cattle, pigs, dogs and cats, and the level of compromised welfare in pigs than students from eastern Croatia and Dalmatia. Students originating from other countries
\end{abstract}

expressed the highest level of concern about the welfare of laying hens, and the lowest about the welfare of dogs and cats. Students from Lika and Gorski Kotar expressed the highest level of concern about the welfare of dogs and cats. No regional differences were determined in student attitudes towards the level of emotions in the observed species. The study results confirmed the existence of regional differences in the attitudes of Croatian veterinary students towards the welfare of farm and companion animals. The findings suggest that these differences may not only be the result of cultural differences among Croatian regions, but veterinary students may also increasingly encounter welfare issues in certain regions, especially in the case of companion animals.

Key words: Croatia; region; veterinary students; farm animals; companion animals; welfare issues

Ivana SABOLEK, DVM, Assistant, Mario OSTOVIĆ*, DVM, PhD, Associate Professor (Corresponding author, e-mail: mostovic@vef.hr), Tomislav MIKUŠ, DVM, PhD, Senior Assistant, Željko PAVIČIĆ, DVM, PhD, Full Professor, Kristina MATKOVIĆ, DVM, PhD, Full Professor, Faculty of Veterinary Medicine, University of Zagreb, Zagreb, Croatia; Boris ANTUNOVIĆ, DVM, PhD, Full Professor, Faculty of Agrobiotechnical Sciences, Josip Juraj Strossmayer University of Osijek, Osijek, Croatia; Željka MESIĆ, Graduate Agronomist, PhD, Assistant Professor, Faculty of Agriculture, University of Zagreb, Zagreb, Croatia 


\section{Introduction}

Animal welfare is a matter of increasing social concern (MarchantForde, 2015; EC, 2016; Vogeler, 2019). However, it has been demonstrated that humans may prefer some animal species to others (Serpell, 2004; de la Fuente et al., 2017). Attitudes towards animals are important because they affect how humans validate animal life, how they behave towards animals, or how they treat them (Ostovic et al., 2017). Besides the animal itself, attitudes towards animals may be influenced by many other factors, such as personal and cultural characteristics (Serpell, 2004; Ormandy and Schuppli, 2014; Borgi and Cirulli, 2015). Personality and the way in which people morally evaluate situations are among the most crucial factors affecting individual empathy for animals (Ormandy and Schuppli, 2014). Urban and rural backgrounds also provide a different cultural experience, playing an important role in shaping human attitudes towards animals (Kendall et al., 2006). In urban areas of developed countries, where people typically have no contact with farm animals, companion animals are regularly considered as family members (Ostovic et al., 2017). Moreover, worldwide differences in the attitudes towards animals and their use may be the result of influences of different cultures and legislations, as well as economic opportunities (Phillips et al., 2012; Špinka, 2012).

As Croatia is a multiregional and multicultural country with different economic strengths across the regions (CCE, 2017), differences in the attitudes towards specific domains of life can be expected. A number of studies have been conducted on regional differences in resident attitudes towards their own well-being in Croatia. Kaliterna Lipovčan et al. (2017) showed that the well-being of coastal area residents was higher than those from inland areas. Lučić et al. (2019) found that the citizens of Zagreb were most satisfied with their work, while satisfaction with family life was highest in eastern Croatia.

The present study aimed to examine the attitudes of veterinary students in Croatia according to the region of their origin towards the welfare of farm and companion animals.

\section{Materials and methods}

The survey was conducted at the Faculty of Veterinary Medicine, University of Zagreb, Zagreb, Croatia, in the autumn semester of the 2013/2014 academic year, and encompassed 505 (91\%) students of all six years of the integrated undergraduate and graduate study programme. All respondents had the same curriculum in the field of animal welfare. The survey was voluntary and anonymous, approved by the institutional Board for Quality Management. Students were familiar with the aims of the survey and informed that the results obtained would be used for educational and scientific purposes.

The written questionnaire was composed of two sections. The first section consisted of demographic and experiential questions, i.e. study year, gender, age, grow-up place, region of origin, previous education, preferred/ chosen study track and information on owning/keeping farm and companion animals. The second section included 17 statements structured of five-point Likert scale questions ( 1 = strongly disagree, 2 = disagree, 3 = neutral/unsure, $4=$ agree, 5 = strongly agree), with higher scores reflecting higher student compassion for farm and companion animals. Questions were focused on the following farm and companion animal species: cattle, pigs, poultry, dogs and cats. 


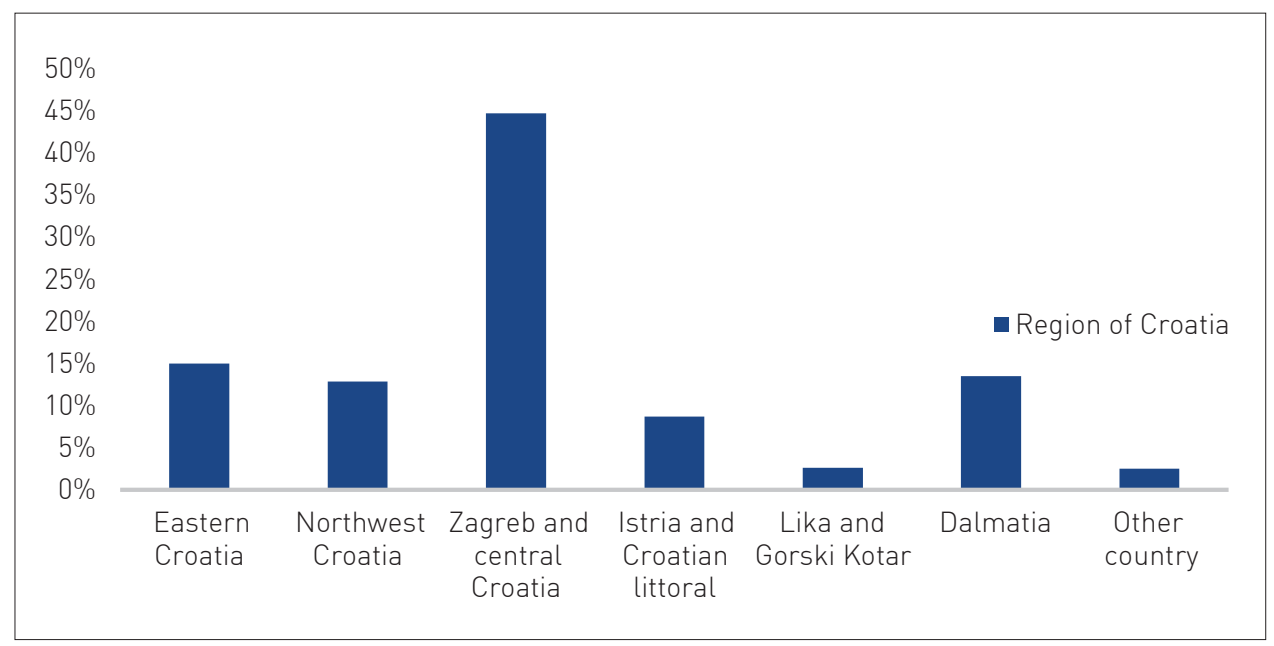

Figure 1. Distribution of veterinary students in Croatia according to region of their origin

Data analysis was performed using SPSS v. 21.0 statistical software. Univariate analysis was used to determine the frequencies of student answers. Regional differences in student answers were tested by Kruskal-Wallis test and Mann-Whitney $U$-test.

\section{Results}

The demographic portion of the study has been reported elsewhere (Ostovic et al., 2017). The distribution of students based on the region of their origin in Croatia was as follows: eastern Croatia (15\%), northwest Croatia (12.9\%), Zagreb and central Croatia (44.8\%), Istria and Croatian littoral $(8.7 \%)$, Lika and Gorski Kotar $(2.6 \%)$, Dalmatia (13.5\%), other country $(2.5 \%)$ (Figure 1$)$.

Of the 17 statements, regional differences were determined for eight statements. For most of these statements, i.e. the level of thought process in cattle, pigs, dogs and cats (Table 1), and the level of compromised welfare in pigs (Table 3 ), students from Zagreb and central Croatia expressed significantly higher attitudes $(P<0.05)$ than students from eastern Croatia and Dalmatia.
There were no regional differences in student attitudes towards the level of thought process in poultry (Table 1), the level of emotions in any species observed (Table 2) or the level of compromised welfare in dairy cows, beef cattle and broilers (Table 3).

Significant differences were found concerning the level of compromised welfare in laying hens, dogs and cats $(P<0.05)$ between students from Croatia and those originating from other countries. The latter students expressed the highest level of concern about the welfare of laying hens, and the lowest about the welfare of dogs and cats (Table 3). As for differences within Croatia, students from Lika and Gorski Kotar expressed significantly higher concern $(P<0.05)$ for the welfare of dogs and cats as compared to all other regions observed (Table 3 ).

\section{Discussion}

Veterinarians are expected to have and promote highly positive attitudes towards all animals and their welfare (Hernandez et al., 2018; Menor-Campos et al., 2019). However, previous studies have shown that veterinary perception of the 
Table 1. Student attitudes towards the level of thought process in farm and companion animals

\begin{tabular}{|c|c|c|c|c|c|}
\hline \multirow{2}{*}{ Region } & Cattle & Pigs & Poultry & Dogs & Cats \\
\hline & \multicolumn{5}{|c|}{ Mean* \pm SEM } \\
\hline Eastern Croatia & $3.70^{\mathrm{a}} \pm 0.11$ & $3.91^{\mathrm{a}, \mathrm{b}} \pm 0.11$ & $2.75 \pm 0.12$ & $4.61^{\mathrm{a}} \pm 0.08$ & $4.32^{\mathrm{a}} \pm 0.11$ \\
\hline Northwest Croatia & $3.97 \pm 0.11$ & $4.29^{a} \pm 0.10$ & $3.05 \pm 0.14$ & $4.77 \pm 0.07$ & $4.62^{b} \pm 0.08$ \\
\hline $\begin{array}{l}\text { Zagreb and central } \\
\text { Croatia }\end{array}$ & $4.08^{a, b} \pm 0.06$ & $4.32^{b, c} \pm 0.05$ & $2.98 \pm 0.08$ & $4.85^{\mathrm{a}, \mathrm{b}, \mathrm{c}} \pm 0.03$ & $4.67^{\mathrm{a}, \mathrm{c}, \mathrm{d}} \pm 0.05$ \\
\hline $\begin{array}{l}\text { Istria and Croatian } \\
\text { littoral }\end{array}$ & $3.81 \pm 0.16$ & $4.05 \pm 0.16$ & $2.68 \pm 0.17$ & $4.66^{b} \pm 0.10$ & $4.46^{c} \pm 0.12$ \\
\hline Lika and Gorski Kotar & $4.15 \pm 0.27$ & $4.39 \pm 0.27$ & $3.23 \pm 0.36$ & $4.69 \pm 0.13$ & $4.69 \pm 0.13$ \\
\hline Dalmatia & $3.69^{b} \pm 0.12$ & $3.93^{c} \pm 0.13$ & $2.88 \pm 0.15$ & $4.75^{c} \pm 0.06$ & $4.32^{b, d} \pm 0.11$ \\
\hline Other country & $4.08 \pm 0.29$ & $4.39 \pm 0.24$ & $3.46 \pm 0.35$ & $4.62 \pm 0.24$ & $4.54 \pm 0.18$ \\
\hline
\end{tabular}

*1 - strongly disagree, 5 - strongly agree; values in the same column marked with the same letter differ significantly $(P<0.05)$

Table 2. Student attitudes towards the level of emotions in farm and companion animals

\begin{tabular}{|l|c|c|c|c|c|}
\hline \multirow{2}{*}{ Region } & Cattle & Pigs & Poultry & Dogs & Cats \\
\cline { 2 - 6 } & \multicolumn{3}{|c|}{ Mean* \pm SEM } \\
\hline Eastern Croatia & $3.92 \pm 0.12$ & $4.01 \pm 0.11$ & $3.15 \pm 0.14$ & $4.66 \pm 0.09$ & $4.33 \pm 0.13$ \\
\hline Northwest Croatia & $4.26 \pm 0.12$ & $4.43 \pm 0.10$ & $3.57 \pm 0.16$ & $4.80 \pm 0.07$ & $4.65 \pm 0.09$ \\
\hline $\begin{array}{l}\text { Zagreb and central } \\
\text { Croatia }\end{array}$ & $4.27 \pm 0.06$ & $4.26 \pm 0.06$ & $3.44 \pm 0.08$ & $4.88 \pm 0.03$ & $4.62 \pm 0.05$ \\
\hline $\begin{array}{l}\text { Istria and Croatian } \\
\text { littoral }\end{array}$ & $4.14 \pm 0.14$ & $4.39 \pm 0.13$ & $3.23 \pm 0.19$ & $4.81 \pm 0.08$ & $4.50 \pm 0.11$ \\
\hline Lika and Gorski Kotar & $4.00 \pm 0.36$ & $4.31 \pm 0.26$ & $3.31 \pm 0.37$ & $4.62 \pm 0.18$ & $4.62 \pm 0.18$ \\
\hline Dalmatia & $4.02 \pm 0.11$ & $4.10 \pm 0.11$ & $3.13 \pm 0.15$ & $4.75 \pm 0.07$ & $4.40 \pm 0.11$ \\
\hline Other country & $4.08 \pm 0.33$ & $3.92 \pm 0.37$ & $3.54 \pm 0.43$ & $4.77 \pm 0.17$ & $4.31 \pm 0.33$ \\
\hline
\end{tabular}

${ }^{*} 1$ - strongly disagree, 5 - strongly agree

Table 3. Student attitudes towards the level of compromised welfare in farm and companion animals

\begin{tabular}{|c|c|c|c|c|c|c|c|}
\hline \multirow{2}{*}{ Region } & $\begin{array}{l}\text { Dairy } \\
\text { cows }\end{array}$ & $\begin{array}{l}\text { Beef } \\
\text { cattle }\end{array}$ & Pigs & Laying hens & Broilers & Dogs & Cats \\
\hline & \multicolumn{7}{|c|}{ Mean* \pm SEM } \\
\hline Eastern Croatia & $3.92 \pm 0.11$ & $3.95 \pm 0.10$ & $3.74^{a} \pm 0.11$ & $4.08 \pm 0.11$ & $4.11 \pm 0.11$ & $3.17^{a, b, c} \pm 0.14$ & $2.86^{\mathrm{a}} \pm 0.13$ \\
\hline $\begin{array}{l}\text { Northwest } \\
\text { Croatia }\end{array}$ & $3.68 \pm 0.11$ & $3.92 \pm 0.12$ & $3.75 \pm 0.13$ & $3.83^{\mathrm{a}} \pm 0.13$ & $3.97 \pm 0.13$ & $3.34^{\mathrm{de}, \mathrm{e}, \mathrm{f} g} \pm 0.14$ & $3.12^{b, c, d} \pm 0.12$ \\
\hline $\begin{array}{l}\text { Zagreb and } \\
\text { central Croatia }\end{array}$ & $3.89 \pm 0.07$ & $4.01 \pm 0.06$ & $3.98^{\mathrm{a}, \mathrm{b}} \pm 0.06$ & $4.11^{b} \pm 0.07$ & $4.10 \pm 0.07$ & $3.16^{h, i, j, k} \pm 0.08$ & $2.93^{e} \pm 0.08$ \\
\hline $\begin{array}{l}\text { Istria and } \\
\text { Croatian littoral }\end{array}$ & $3.84 \pm 0.16$ & $4.11 \pm 0.13$ & $3.96^{c} \pm 0.15$ & $4.16^{c} \pm 0.16$ & $4.25 \pm 0.15$ & $2.66^{\mathrm{a}, \mathrm{d}, \mathrm{h}, \mathrm{l}} \pm 0.16$ & $2.59^{\mathrm{b}, \mathrm{f}} \pm 0.16$ \\
\hline $\begin{array}{l}\text { Lika and } \\
\text { Gorski Kotar }\end{array}$ & $3.69 \pm 0.43$ & $3.85 \pm 0.37$ & $3.92 \pm 0.35$ & $3.69 \pm 0.40$ & $4.00 \pm 0.34$ & $4.08^{b, e, i, l, m, n} \pm 0.27$ & $3.85^{\text {a,c,e,f,g,h }} \pm 0.25$ \\
\hline Dalmatia & $3.88 \pm 0.13$ & $3.78 \pm 0.13$ & $3.56^{b, c} \pm 0.13$ & $3.78^{b, c, d} \pm 0.13$ & $3.69 \pm 0.15$ & $2.81^{\mathrm{ft}, \mathrm{m} m} \pm 0.15$ & $2.72^{\mathrm{d}, 9} \pm 0.14$ \\
\hline Other country & $4.39 \pm 0.27$ & $4.08 \pm 0.31$ & $4.15 \pm 0.32$ & $4.46^{\mathrm{a}, \mathrm{d}} \pm 0.31$ & $4.23 \pm 0.32$ & $2.31^{c, g, k, n} \pm 0.35$ & $2.46^{h} \pm 0.37$ \\
\hline
\end{tabular}

${ }^{*} 1$ - strongly disagree, 5 - strongly agree; values in the same column marked with the same letter differ significantly $(P<0.05)$ 
issue may also differ regarding different animal species (Levine et al., 2005; Hazel et al., 2011; Magnani et al., 2017; Mariti et al., 2018; Pirrone et al., 2019), as well as demographics (Izmirli and Phillips, 2012; Pirrone et al., 2019). This study examined the regional differences in the attitudes of Croatian veterinarians-to-be towards the level of cognitive abilities in farm and companion animals, and whether their welfare was compromised.

The results showed that students from all regions agreed that cattle, pigs and cats, and fully agreed that dogs were capable of thought process and having emotions. They also considered that welfare of dairy cows, beef cattle and pigs was compromised. Yet, students from Zagreb and central Croatia expressed a significantly higher rate of agreement that cattle, pigs, dogs and cats were capable of thought process and that the welfare of pigs was compromised as compared to students from eastern Croatia and Dalmatia. These findings could be explained by the fact that people living in more urban settings and keeping companion animals tend to have more positive attitudes towards both farm and companion animals and their welfare (Pifer et al., 1994; Ormandy and Schuppli, 2014). Therefore, they were more likely to express greater concern for the welfare of pigs, possibly because this species undergoes more management practices than cattle. In urban settings, animals are commonly named, provided with toys, attributed human features, protected from any harm, given medical care and even buried when they die (Ostovic et al., 2017). This could be the reason that all students were not sure whether the welfare of dogs and cats was compromised, except for students from Lika and Gorski Kotar, and students originating from other countries. Students from Lika and Gorski Kotar expressed significantly more concern for the welfare of dogs and cats than students from all other regions, suggesting that these students may be increasingly facing welfare issues in these species in their region. This could be due to the weak demographic and economic development in the Lika region (CCE, 2017), which is supported by the findings that students originating from other countries were least concerned about the welfare of dogs and cats.

Students from all regions were not so convinced whether poultry are capable of thought process and having emotions, as also supported by other studies (Levine et al., 2005), although they all considered that the welfare of laying hens and broilers was compromised. Nevertheless, students originating from other countries expressed the highest concern for the welfare of laying hens. Across Europe, great efforts have been invested to increase the welfare of laying hens. In the European Union, conventional cages have been banned since 2012 (Anonymous, 1999) and in Croatia since 2014 (Anonymous, 2011). These alterations in poultry production likely received higher media attention and more marketing attention in other European Union countries than in Croatia, which could explain the results obtained. In many countries, following trends will be to move away from enriched cages towards alternative cage-free production systems (van Horne, 2019).

\section{Conclusions}

The study results showed that there are regional differences in the attitudes of Croatian veterinary students towards the welfare of farm and companion animals, i.e. the level of thought process, and the level of compromised welfare in these animals. This is not surprising as Croatia is a multiregional and multicultural country. These differences may not only be the result of cultural differences, but veterinary students may also increasingly encounter welfare issues in particular 
Croatian regions, especially in the case of companion animals.

\section{Acknowledgement}

The authors are grateful to all students having completed the questionnaire.

\section{References}

1. Anon. (1999): Council Directive 1999/74/EC of 19 July 1999 laying down minimum standards for the protection of laying hens. O. J. L 203/53.

2. Anon. (2011): Ordinance amending the Ordinance on the minimum requirements for the protection of laying hens. Official Journal of the Republic of Croatia, No. 51. (in Croatian)

3. BORGI, M. and F. CIRULLI (2015): Attitudes toward animals among kindergarten children: species preferences. Anthrozoös 28, 45-59.

4. CCE (2017): CCE economic power index. Zagreb: Croatian Chamber of Economy (in Croatian) [https://www.hgk.hr/documents/hgk-indeksgospodarske-snage-07201759803f707ec38.pdf, April 2020)]

5. DE LA FUENTE, M. F. C., A. SOUTO, C. B. CASELLI and N. SCHIEL (2017): People's perception on animal welfare: why does it matter? Ethnobiol. Conserv. 6, 18.

6. EC (2016): Attitudes of Europeans towards animal welfare. Special Eurobarometer 442 Report. Brussels: European Commission.

7. HAZEL, S. J., T. D. SIGNAL and N. TAYLOR (2011): Can teaching veterinary and animal-science students about animal welfare affect their attitude toward animals and human-related empathy? J. Vet. Med. Educ. 38, 74-83.

8. HERNANDEZ, E., A. FAWCETT, E. BROUWER, J. RAU and P. V. TURNER (2018): Speaking up: veterinary ethical responsibilities and animal welfare issues in everyday practice. Animals 8, 15.

9. IZMIRLI, S. and C. J. PHILLIPS (2012): Attitudes of Australian and Turkish veterinary faculty toward animal welfare. J. Vet. Med. Educ. 39, 200-207.

10. KALITERNA LIPOVČAN, LJ., T. BABAROVIĆ and A. BRAJŠA-ŽGANEC (2017): Subjective well-being in Croatia: differences between the Adriatic coast and the continent. In: Jurčević, K., Lj. Kaliterna Lipovčan, O. Ramljak: Imagining the Mediterranean: challenges and perspectives. Zagreb, Croatia (337-346).

11. KENDALL, H. A., L. M. LOBAO and J. S. SHARP (2006): Public concern with animal well-being: place, social structural location, and individual experience. Rural Sociol. 71, 399-428.

12. LEVINE, E. D., D. S. MILLS and K. A. HOUPT (2005): Attitudes of veterinary students at one US college toward factors relating to farm animal welfare. J. Vet. Med. Educ. 32, 481-490.
13. LUČIĆ, L., T. BRKLJAČIĆ, LJ. KALITERNA LIPOVČAN, I. SUČIĆ and A. BRAJŠA-ŽGANEC (2019): Regional differences in well-being in Croatia. In: Jurčević, K., Lj. Kaliterna Lipovčan, O. Ramljak: Reflections on the Mediterranean. Zagreb, Croatia (221-230).

14. MAGNANI, D., N. FERRI, A. DALMAU and S. MESSORI (2017): Knowledge and opinions of veterinary students in Italy toward animal welfare science and law. Vet. Rec. 180, 225.

15. MARCHANT-FORDE, J. N. (2015): The science of animal behavior and welfare: challenges, opportunities, and global perspective. Front. Vet. Sci. 2, 16.

16. MARITI, C., F. PIRRONE, M. ALBERTINI, A. GAZZANO and S. DIVERIO (2018): Familiarity and interest in working with livestock decreases the odds of having positive attitudes towards nonhuman animals and their welfare among veterinary students in Italy. Animals 8, 150.

17. MENOR-CAMPOS, D. J., S. DIVERIO, C. SÁNCHEZ-MUÑOZ, R. LÓPEZ-RODRÍGUEZ, A GAZZANO, L. PALANDRI and C. MARITI (2019): Attitudes toward animals of students at three European veterinary medicine schools in Italy and Spain. Anthrozoös 32, 375-385.

18. ORMANDY, E. H. and C. A. SCHUPPLI (2014): Public attitudes toward animal research: a review. Animals 4, 391-408.

19. OSTOVIC, M., T. MIKUS, Z. PAVICIC, K. MATKOVIC and Z. MESIC (2017): Influence of socio-demographic and experiential factors on the attitudes of Croatian veterinary students towards farm animal welfare. Vet. Med.-Czech 62, 417-428.

20. PHILLIPS, C. J. C., S. IZMIRLI, S. J. ALDAVOOD et al. (2012): Students' attitudes to animal welfare and rights in Europe and Asia. Anim. Welf. 21, 87-100.

21. PIFER, L., K. SHIMIZU and R. PIFER (1994): Public attitudes toward animal research: some international comparisons. Soc. Anim. 2, 95-113.

22. PIRRONE, F., C. MARITI, A. GAZZANO, M. ALBERTINI, C. SIGHIERI and S. DIVERIO (2019): Attitudes toward animals and their welfare among Italian veterinary students. Vet. Sci. 6, 19.

23. SERPELL, J. A. (2004): Factors influencing human attitudes to animals and their welfare. Anim. Welf. 13, 145-151.

24. ŠPINKA, M. (2012): AWARE project: background, objectives and expected outcomes. $63^{\text {rd }}$ Annual Meeting of the European Federation of Animal Science (EAAP) (Bratislava, 27-31 August 2012). Book of Abstracts. Wageningen (205).

25. VAN HORNE, P. L. M. (2019): Competitiveness of the EU egg sector, base year 2017. International comparison of production costs. Report 2019-008. Wageningen: Wageningen Economic Research.

26. VOGELER, S. C. (2019): Market-based governance in farm animal welfare - A comparative analysis of public and private policies in Germany and France. Animals 9, 267. 


\section{Regionalne razlike u stavovima studenata veterinarske medicine u Hrvatskoj o dobrobiti farmskih životinja i kućnih ljubimaca}

Ivana SABOLEK, dr. med. vet., asistentica, dr. sc. Mario OSTOVIĆ, dr. med. vet., izvanredni profesor, dr. sc. Tomislav MIKUŠ, dr. med. vet., viši asistent, dr. sc. Željko PAVIČIĆ, dr. med. vet., redoviti profesor, dr. sc. Kristina MATKOVIĆ, dr. med. vet., redovita profesorica, Veterinarski fakultet Sveučilišta u Zagrebu, Zagreb, Hrvatska; dr. sc. Boris ANTUNOVIĆ, dr. med. vet., redoviti profesor, Fakultet agrobiotehničkih znanosti Sveučilišta Josipa Jurja Strossmayera u Osijeku, Osijek, Hrvatska; dr. sc. Željka MESIĆ, dipl. ing. agr., docentica, Agronomski fakultet Sveučilišta u Zagrebu, Zagreb, Hrvatska

Cilj je ovoga rada bio ustvrditi razlike u stavovima studenata veterinarske medicine u Hrvatskoj s obzirom na regiju iz koje potječu o razini kognitivnih sposobnosti i narušenosti dobrobiti farmskih životinja i kućnih ljubimaca. U istraživanju je sudjelovalo $505(91 \%)$ studenata svih šest godina integriranog preddiplomskog i diplomskog studija Veterinarskog fakulteta Sveučilišta u Zagrebu, Zagreb, Hrvatska. Stavovi studenata ustvrđeni su na temelju 17 izjava prema Likertovoj mjernoj ljestvici od pet stupnjeva. Izjave su se odnosile na goveda, svinje, perad, pse i mačke. Prema dobivenim rezultatima studenti iz Zagreba i središnje Hrvatske značajno više smatraju $(P<0,05)$ da goveda, svinje, psi i mačke mogu misliti te da svinje imaju narušenu dobrobit, u odnosu na studente iz istočne Hrvatske i Dalmacije. Studenti koji su većinu života proveli u drugim državama iskazali su najveću zabrinutost za dobrobit kokoši nesilica, a najmanju za dobrobit pasa i mačaka. Studenti iz Like i Gorskog Kotara najviše su zabrinuti za dobrobit pasa i mačaka. Nisu ustvrđene regionalne razlike $\mathrm{u}$ stavovima studenata o osjećajima niti $u$ jedne istraživane vrste životinja. Rezultati istraživanja pokazali su da o dobrobiti farmskih životinja i kućnih ljubimaca postoje regionalne razlike $u$ stavovima studenata veterinarske medicine u Hrvatskoj. Dobiveni rezultati upućuju na to da ustvrđene razlike nisu rezultat samo kulturoloških razlika između regija Hrvatske, nego i da se studenti u pojedinim regijama sve više susreću s problemima dobrobiti životinja, osobito kućnih ljubimaca.

Ključne riječi: Hrvatska, regija, studenti veterinarske medicine, farmske životinje, kućni ljubimci, problemi dobrobiti 